\title{
Bacteremia due to Pasteurella dagmatis acquired from a dog bite, with a review of systemic infections and challenges in laboratory identification
}

\author{
Jianhui Xiong $\mathrm{PhD}^{1}$, Sigmund Krajden $\mathrm{MD}^{2,3,5}$, Julianne V Kus $\mathrm{PhD}^{4,5}$, Prasad Rawte MSc ${ }^{4}$, John Blondal MD ${ }^{3}$, \\ Mark Downing $\mathrm{MD}^{2,3}$, Urszula Zurawska $\mathrm{MD}^{3}$, William Chapman $\mathrm{MD}^{1,5}$
}

\begin{abstract}
J Xiong, S Krajden, JV Kus, et al. Bacteremia due to Pasteurella dagmatis acquired from a dog bite, with a review of systemic infections and challenges in laboratory identification. Can J Infect Dis Med Microbiol 2015;26(5):273-276.

A case of bacteremia in a 74-year-old man, which was caused by Pasteurella dagmatis and complicated by thrombocytopenia, is presented. Microorganism identification was performed by the provincial reference laboratory using traditional biochemical profiling, completmented with both the sequencing of the 16S ribosomal RNA gene and matrix-assisted laser desorption/ionization time-of-flight mass spectrometry; antibiotic-susceptibility testing was also performed. After treatment with the appropriate antibiotics, the patient fully recovered. Systemic infections attributed to this organism are rarely reported in the literature. Other reported cases of bacteremia due to $P$ dagmatis are reviewed and compared with the present case. The challenges of relying on standard automatic identification are discussed, with alternative methodologies provided.
\end{abstract}

Key Words: 16S rRNA gene sequencing; Bacteremia; Dog bite; Identification; MALDI-ToF MS; Pasteurella dagmatis; VITEK 2

\section{CASE PRESENTATION}

A 74-year-old man startled his dog and sustained a penetrating bite to his hand. The dog then licked the blood off the injured extremity. A few days later, the patient developed fever, chills and weakness, resulting in a fall. He presented to the emergency room for assessment. Medical history and significant comorbidities included chronic obstructive pulmonary disease, hypertension, dyslipidemia and idiopathic dilated cardiomyopathy, Grade 3 left ventricle. No immunocompromising illnesses were present. Physical examination revealed a temperature of $40^{\circ} \mathrm{C}$, with bronchial breath sounds and crackles heard in the left chest; the bite wound appeared improved. A chest $\mathrm{x}$-ray revealed a left perihilar infiltrate. Peripheral white blood cell count was $15.5 \times 10^{9} / \mathrm{L}$, neutrophils $13.4 \times 10^{9} / \mathrm{L}$, hemoglobin $126 \mathrm{~g} / \mathrm{L}$ and platelet nadir $14,000 \times 10^{9} / \mathrm{L}$. The patient was admitted for further investigation and treatment. Blood cultures grew coagulasenegative Staphylococcus, which was considered to be a contaminant, and Gram-negative coccobacilli were later determined to be Pasteurella dagmatis. Treatment was initiated with oral azithromycin $500 \mathrm{mg}$ per day and intravenous ceftriaxone $1 \mathrm{~g}$ every $24 \mathrm{~h}$ for five days. The patient defervesced within four days and his condition improved dramatically. Oral levofloxacin $500 \mathrm{mg}$ was administered as step-down therapy for 10 days. The hematological abnormalities resolved. On follow-up three months later, he remained well.

\author{
Une bactériémie à Pasteurella dagmatis contractée \\ par une morsure de chien, une analyse des \\ infections systémiques et les difficultés pour le \\ dépistage en laboratoire
}

Les auteurs présentent un cas de bactériémie chez un homme de 74 ans, causé par un Pasteurella dagmatis et compliqué par une thrombocytopénie. Le laboratoire de référence provincial a identifié le microorganisme au moyen du profilage biochimique classique et l'a complété par le séquençage du gène de l'ARN ribosomique $16 \mathrm{~S}$ et par la spectrométrie de masse à temps de vol par désorption-ionisation laser assistée par matrice. Le laboratoire a également effectué un test de susceptibilité aux antibiotiques. Après un traitement antibiotique pertinent, le patient s'est complètement rétabli. Les publications scientifiques contiennent peu de déclarations d'infections systémiques attribuées à cet organisme. D'autres cas de bactériémie à $P$ dagmatis sont analysés et comparés à la présente situation. Les problèmes liés à l'identification automatique standard sont exposés et d'autres méthodologies sont proposées.

${ }^{1}$ Department of Laboratory Medicine; ${ }^{2}$ Division of Infectious Diseases; ${ }^{3}$ Internal Medicine of St Joseph's Health Centre; ${ }^{4}$ Public Health Ontario;

${ }^{5}$ Department of Laboratory Medicine and Pathobiology, University of Toronto, Toronto, Ontario

Correspondence: Dr Sigmund Krajden, Department of Internal Medicine, St Joseph's Health Centre, 30 The Queensway, Toronto,

Ontario M6R 1B5. Telephone 416-530-6000, fax 416-530-6590, e-mail krajds@stjoe.on.ca 
TABLE 1

Antibiotic susceptibility of Pasteurella dagmatis

\begin{tabular}{|c|c|c|}
\hline Antibiotic & $\begin{array}{l}\text { Mininmum inhibitory } \\
\text { concentration, } \mathrm{mg} / \mathrm{L}\end{array}$ & Interpretation \\
\hline Penicillin & 0.12 & Sensitive \\
\hline Ampicillin & $\leq 2$ & Sensitive \\
\hline Pipercillin/tazobactum & $\leq 4$ & Sensitive \\
\hline Cefazolin & $\leq 4$ & Sensitive \\
\hline Ceftazidime/ceftriaxone & $\leq 1$ & Sensitive \\
\hline Meropenem & $\leq 0.25$ & Sensitive \\
\hline Gentamicin/tobramycin & $\leq 1$ & Sensitive \\
\hline Ciprofloxacin & $\leq 0.25$ & Sensitive \\
\hline Levofloxacin & $\leq 0.03$ & Sensitive \\
\hline Trimetoprim/sulfamethoxazole & $\leq 20$ & Sensitive \\
\hline
\end{tabular}

Analysis performed using VITEK 2 (BioMerieux, France) and agar dilution as per the Clinical and Laboratory Standards Institute (1)

TABLE 2

Key biochemical characteristics of Pasteurella dagmatis, $P$ stomatis and $P$ pneumotropica

\begin{tabular}{lccc}
\hline & $P$ dagmatis & $P$ stomatis & $P$ pneumotropica \\
\hline Dextrose & + & + & $\mathrm{n} / \mathrm{a}$ \\
Lactose & - & - & - \\
Sucrose & + & + & + \\
Xylose & - & - & + \\
Mannitol & - & - & - \\
Maltose & + & - & + \\
Arabinose & - & - & $\mathrm{V}$ \\
Sorbitol & - & - & - \\
Trelose & + & + & + \\
Dulcitol & - & - & - \\
Catalase & + & + & + \\
Oxidase & + & + & + \\
TSI slant/butt & $+/+$ & $+/+$ & $+/+$ \\
Indole & + & + & + \\
Urea activity & + & - & + \\
Nitrate to nitrite & + & + & + \\
Motility & - & - & - \\
Ornithine & - & - & + \\
Arginine & - & - & $\mathrm{n} / \mathrm{a}$ \\
Lysine & - & - & $\mathrm{V}$ \\
Ortho-nitrophenyl- $\beta$-galactoside & - & - & +
\end{tabular}

Data presented as positive (+) or negative (-). Reactions refer to reference 2. $n / a$ Not available; $V$ Variable;

Biochemical profile

Traditional biochemical testing was performed on the isolate and based on its profile was determined to be $P$ dagmatis (2) (Table 2). Because this organism is not often encountered, alternate identification methods were also used to ensure a correct identification.

16S rRNA gene PCR/sequencing

16S rRNA gene PCR was performed at Public Health Ontario. A 736-base pair amplicon was generated (primers, forward: 5'-AGTTTGATCCTGGCTCAG-3'; Reverse: 5'GGACTACCAGGGTATCTAAT-3') and sequenced using routine methods (3). The sequence was analyzed using National Center for Biotechnology Information basic local alignment search tool (4) and results were interpreted using CLSI MM18-A guidelines (5). The PCR product was $99 \%$ similar to six deposits within the $\mathrm{nr} / \mathrm{nt}$ database with $99 \%$ to $100 \%$ coverage. Sequences with high
TABLE 3

Summary of reports involving bacteremia in humans with Pasteuralla dagmatis in the English literature

\begin{tabular}{|c|c|c|c|c|c|}
\hline $\begin{array}{l}\text { Patient } \\
\text { age, } \\
\text { years/sex }\end{array}$ & $\begin{array}{l}\text { Animal } \\
\text { bites }\end{array}$ & Diagnosis & $\begin{array}{l}\text { Antibiotic } \\
\text { Treatment }\end{array}$ & Outcome & Reference \\
\hline 78/male & None & $\begin{array}{c}\text { Prosthetic valve } \\
\text { endocarditis }\end{array}$ & Ceftriaxone & Survived & 10 \\
\hline $66 /$ male & None & Septicemia & Penicillin & Recovered & 11 \\
\hline $51 /$ male & Dog & $\begin{array}{l}\text { Septicemia, } \\
\text { diabetic foot }\end{array}$ & Penicillin & Resolved & 12 \\
\hline 55/female & Cat & $\begin{array}{l}\text { Infectious endo- } \\
\text { carditis throm- } \\
\text { bocytopenia }\end{array}$ & Ceftriaxone & Survived & 14 \\
\hline $77 /$ male & Cat & $\begin{array}{c}\text { Prosthetic valve } \\
\text { endocarditis }\end{array}$ & $\begin{array}{l}\text { Ceftriaxone, } \\
\text { penicillin }\end{array}$ & Recovered & 15 \\
\hline $56 /$ female & Dog & $\begin{array}{l}\text { Peritonitis, } \\
\text { septicemia, } \\
\text { cirrhosis }\end{array}$ & $\begin{array}{c}\text { Benzypenicillin, } \\
\text { ciprofloxacin, } \\
\text { metronidazole }\end{array}$ & $\begin{array}{c}\text { Passed } \\
\text { away } \\
\text { within } \\
24 \text { h }\end{array}$ & 16 \\
\hline
\end{tabular}

levels of homology to the query sequence included the type strain of $P$ dagmatis, ATCC 43325/CCUG 12397 (99\%; NR_042883.1 and M75051.1) and the type strain of Pasteurella stomatis, CCUG 17979 (99\%; NR_042888.1). Based on CLSI MM18-A interpretation guidelines (5), due to the low level of demarcation of the sequence of the 16S rRNA gene between these species, the unknown bacteria may only be identified as $P$ dagmatis or $P$ stomatis. However, based on the biochemical profile (Table 2), this organism could not be $P$ stomatis (which is urease and maltose negative, because the organism in question is urease and maltose positive); therefore, in the present case, the identification of the organism was $P$ dagmatis.

\section{MALDI-ToF MS}

Single colonies of fresh organisms grown overnight were prepared using a modified formic acid extraction procedure and analyzed using the Bruker MALDI BioTyper (Bruker Daltonics, Germany) in duplicate using standard settings. The query spectra had a high level of similarity $>2.0$ ( $\geq 2.0$ is an acceptable score for species-level identification) to $P$ dagmatis spectra within the routine commercial database. The top five matches were to spectra from different strains of $P$ dagmatis within the commercial database.

\section{DISCUSSION AND LITERATURE REVIEW}

$P$ dagmatis is a relatively new species for many clinicians. It is a Gram-negative coccobacillus belonging to the Pasteurellaceae family, which is fermentative, aerobic, nonmotile, oxidase positive and penicillin-sensitive. This organism has been isolated from both dogs and cats as normal flora, and also reported as a pathogen in human infections. It was previously labeled as Pasteurella "gas", Pasteurella new species 1 or $P$ pneumotropica type Henriksen, and was eventually reclassified as $P$ dagmatis (6)

Bacteria from the Pasteurellaceae family cause zoonotic infections in humans, with $P$ multocida and $P$ canis being the most common Pasturella species reported in human infections $(7,8)$. Infections caused by Pasteurella species are typically introduced by animals, particularly cat or dog bites, but also occasionally by other animals, and often manifest as skin or soft tissue infections (7-9). Sometimes, animal contact is not prominent in the initial patient history $(10,11)$ (Table 3). The most probable route of transmission of $P$ dagmatis infection in the present case was most likely the bite and licking of the patient's traumatized skin by his dog, as has been previously described $(11,12)$. Continuous shedding of $P$ dagmatis from asymptomatic animals (eg, in dog urine [13]) and whether it can be an indirect route of infection to human remains to be investigated. 
While Pasteurella species are well recognized for causing skin or soft tissue infections, $P$ dagmatis can also cause more serious disease, including infective and prosthetic valve endocarditis $(10,14,15)$, septicemia $(11,12,16)$, peritonitis $(17)$, vertebral osteomyelitis $(18,19)$, chronic bronchiectasis (20) and pneumonia (21), mainly in immunocompromised patients. A small number of case reports describing systemic human $P$ dagmatis infections are listed in Table 3. Interestingly, while Pasturella species infrequently cause systemic infectious disease, in our review of the literature, when $P$ dagmatis infections are reported, they appear to be frequently associated with severe disseminated infection including bacteremia. Coinfections of $P$ dagmatis with another Pasturella species have also been observed $(9,12,22)$; therefore, it is important for the laboratory to test multiple morphotypes from the plate to ensure that $>1$ Pasturella species is not present.

Similar to other Pasturella species, P dagmatis is typically highly susceptible to many antibiotics, particularly, the beta-lactams (Table 1). Early suspicion and timely laboratory diagnosis of Pasturella infection are crucial for a favourable clinical outcome.

Several reports have demonstrated that the VITEK 2 GN card misidentifies $P$ dagmatis as $P$ pneumotropica or $P$ canis, despite an excellent identification probability $(9,15,23,24)$. This is most likely because $P$ dagmatis has not been included in the system database; as well, there has been a nomenclature change because $P$ dagmatis was formerly grouped with $P$ pneumotropica, type Henriksen. In a study that included 66 clinical Pasturella isolates and used sodA gene sequencing as a reference method, Zangenah et al (24) revealed that VITEK 2 only identified approximately 50\% of Pasturella isolates correctly, while conventional biochemical tests and MALDI-ToF MS were able to correctly identify $94 \%$ and $89 \%$, respectively. Interestingly, in the Zangenah et al (24) study, two P dagmatis isolates were not identified by VITEK MS MALDI-ToF (BioMerieux, France) and this limitation was also observed in our study (data not shown). The biological and genetic profiles among $P$ dagmatis, $P$ pneumotropica and $P$ stomatis are very similar (Table 2 ); both a commercial biochemical identification system and the sequence analysis of a portion of the $16 \mathrm{~S}$ rRNA gene were unable to differentiate between these species.
Correct identification was made using MALDI-ToF MS (MALDI Biotyper, Bruker, Germany) and was also supported by comparing the key biochemical characteristics among $P$ dagmatis, $P$ pneumotropica and $P$ stomatis (Table 2). It is probable that many clinical isolates of $P$ dagmatis have been misidentified due to the limitation of commercial biochemical identification systems, such as VITEK 2. Misidentification may have contributed to an underestimation of the frequency of this organism in clinical samples; however, the growing use of MALDI-ToF MS systems for microorganism identification in routine clinical microbiology laboratories may allow for a more accurate picture of how frequently $P$ dagmatis causes infections. Correct identification is important for diagnosis and therapeutic management, and epidemiological monitoring of the transmission of Pasturella species, particularly for the systemic infections such as in the present case. Unfortunately, most routine methods available at hospital laboratories cannot identify the organism correctly.

\section{CONCLUSION}

$P$ dagmatis can cause severe animal-associated infections in humans, mainly in immunocompromised individuals. To our knowledge, this is the first systemic $P$ dagmatis infection reported in Canada. Clinical outcomes rely on early accurate laboratory confirmation and timely administration of effective antibiotic treatment. Conventional identification of $P$ dagmatis using VITEK 2 can be misleading, probably due to the absence of this organism from the database; $16 \mathrm{~S}$ rRNA gene sequence analysis and MALDI-ToF MS systems represent excellent options for identifying rarely encountered or difficult to identify organisms, such as members of the Pasturellaceae family. The present study re-emphasizes the need for continuously improving the database of automatic microbial identification systems.

ACKNOWLEDGEMENTS: The authors thank the microbiology laboratory staff from SJHC and PHOL for their help and support of this study.

DISCLOSURES: The authors have no financial relationships or conflicts of interest to declare.

\section{REFERENCES}

1. Clinical and Laboratory Standards Institute. Methods for antimicrobial dilution and disk susceptibility testing of infrequently isolated or fastidious bacteria; approved guideline - second edition. CLSI document M45-A2. Wayne: 19087-1898. Clinical and Laboratory Standards Institute; 2010.

2. Weyant R, Moss CW, Weaver RE, et al. Identification of unusual pathogenic Gram-negative aerobic and facultatively anaerobic bacteria. In: Hensyl WR, 2nd edn. Philadelphia: Lippincott Williams and Wilkins, 1996:445-67.

3. Knox M, Cevellos V, and Dean D. 16S ribosomal DNA typing for identification of pathogens in patients with bacterial keratitis. J Clin Microbiol 1998;36:3492-6.

4. Altschul SF, Gish W, Miller W, Myers EW, Lipman DJ. Basic local alignment search tool. J Mol Biol 1990;215:403-10.

5. Clinical and Laboratory Standards Institute. Interpretive criteria for identification of bacteria and fungi by DNA target sequencing; approved guideline - first edition. CLSI document MM18-A. Wayne: 190871898. Clinical and Laboratory Standards Institute; 2008.

6. Mutters R, Ihm P, Pohl S, Frederiksen W, Mannheim W. Reclassification of the genus Pasteurella trevisan 1887 on the basis of deoxyribonucleic acid homology, with proposals for the new species Pasteurella dagmatis, Pasteurella canis, Pasteurella stomatis, Pasteurella anatis, and Pasteurella langaa. Int J Sys Bacteriol 1985; 35:309-22.

7. Abrahamian FM, Goldstein EJC. Microbiology of animal bite wound infections. Clin Microbiol Rev 2011;24:231-46.

8. Talan DA, Citron DM, Abrahamian FM, Moran GJ, Goldstein EJC. Bacteriological analysis of infected dog and cat bites. N Engl J Med 1999;340:85-92.

\section{Akahane T, Nagata M, Matsumoto T, et al. A case of wound dual infection with Pasteurella dagmatis and Pasteurella canis resulting from a dog bite - limitations of Vitek-2 system in exact identification of Pasteurella species. Eur J Med Res 2011; 16:531-6.}

10. Rosenbach KA, Poblete J, Larkin I. Prosthetic valve endocarditis caused by Pasteurella dagmatis. South Med J 2001;94:1033-5.

11. Deschilder I, Gordts B, Van Landuyt H, Renders F, Selleslag D. Pasteurella dagmatis septicemia in an immunocompromised patient without a history of dog or cat bites. Acta Clin Belg J 2000;55:225-6.

12. Fajfar-Whetstone CJ, Coleman L, Biggs DR, Fox BC. Pasteurella multocida septicemia and subsequent Pasteurella dagmatis septicemia in a diabetic patient. J Clin Microbiol 1995;33:202-4.

13. Mosallanejad B, Avizeh R, Ghadiri AR, Moarrabi A, Naddaf H, Jamshidian M. First report of Pasteurella dagmatis isolation from a bitch urine in Iran. Iranian J Vet Res 2008;9:384-6.

14. Sorbello AF, O'Donnell J, Kaiser-Smith J, Fitzharris J, Shinkarow J, Doneson S. Infective endocarditis due to Pasteurella dagmatis: Case report and review. Clin Infect Dis 1994;18:336-8.

15. Strahm C, Goldenberger D, Gutmann M, Kuhnert P, Graber P. Prosthetic valve endocarditis caused by a Pasteurella dagmatis-like isolate originating from a patient's cat. J Clin Microbiol 2012;50:2818-9.

16. Ashley BD, Noone M, Dwarakanath AD, Malnick H. Fatal Pasteurella dagmatis peritonitis and septicaemia in a patient with cirrhosis: A case report and review of the literature. J Clin Pathol 2004;57:210-2.

17. Wallet F, Toure F, Devalckenaere A, Pagniez D, Courcol RJ. Molecular identification of Pasteurella dagmatis peritonitis in a patient undergoing peritoneal dialysis. J Clin Microbiol 2000;38:4681-2.

18. Garcia-Hejl C, Bigaillon C, Garcia C, et al. Pasteurella dagmatis: An unusal cause of vetebral osteomyelitis. J Pathobiol 2007;55:340-2. 


\section{Xiong et al}

19. Dupuy O, Garrabe E, Bordier L, et al. Pasteurella dagmatis spondylodiscitis in a diabetic patient. Revue de Medecine Interne 2006;27:803-4.

20. Allison K, Clarridge JE. Long-term respiratory tract infection with canine-associated Pasteurella dagmatis and Neisseria canis in a patient with chronic bronchiectasis. J Clin Microbiol 2005;43:4272-4.

21. Laurens C, Marouze N, Jean-Pierre H. Staphylococcus pseudintermedius and Pasteurella dagmatis associated in a case of community-acquired pneumonia. Medecine et Maladies Infectieuses 2012;42:129-31.

22. Zbinden R, Sommerhalder P, von Wartburg U. Co-isolation of Pasteurella dagmatis and Pasteurella multocida from cat-bite wounds. Eur J Clin Microbiol \& Infect Dis 1988;7:203-4.
23. Guillard T, Duval V, Jobart R, et al. Dog bite wound infection by Pasteurella dagmatis misidentified as Pasteurella pneumotropica by automated system Vitek 2. Diag Microbiol and Infect Dis 2009;65:347-8.

24. Zangenah S, Güleryüz G, Boräng S, Ullberg M, Bergman P, Ozenci V. Identification of clinical Pasteurella isolates by MALDI-TOF - a comparison with VITEK 2 and conventional microbiological methods. Diag Microbiol and Infect Dis 2013;77:96-8. 


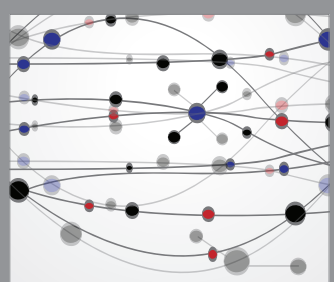

The Scientific World Journal
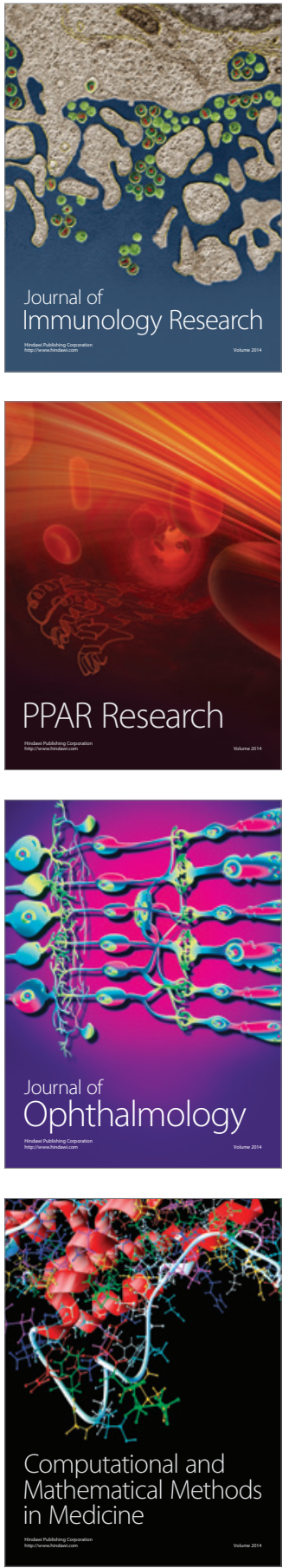

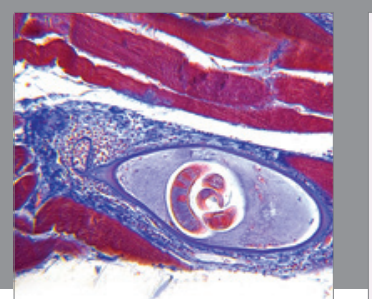

Gastroenterology Research and Practice

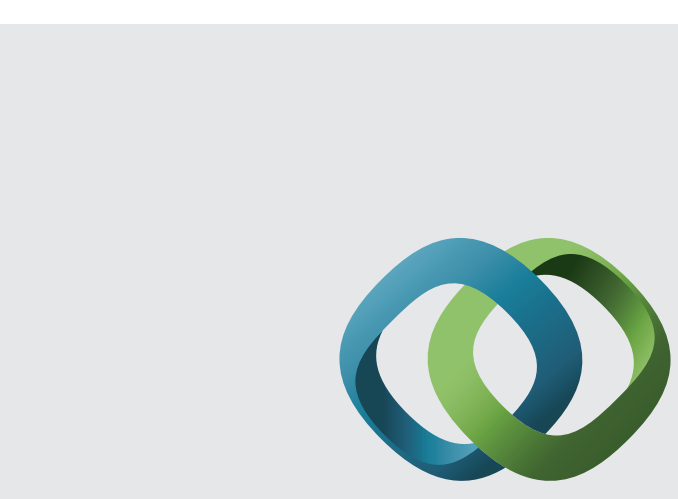

\section{Hindawi}

Submit your manuscripts at

http://www.hindawi.com
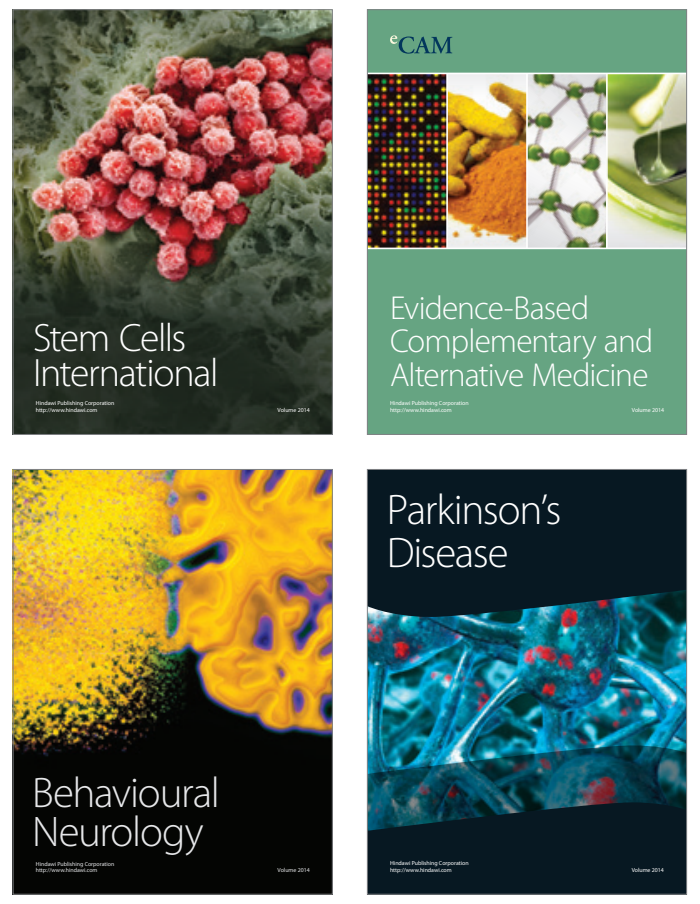
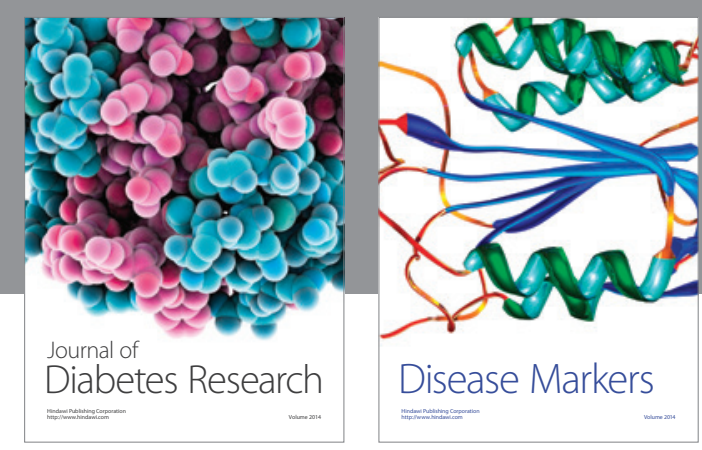

Disease Markers
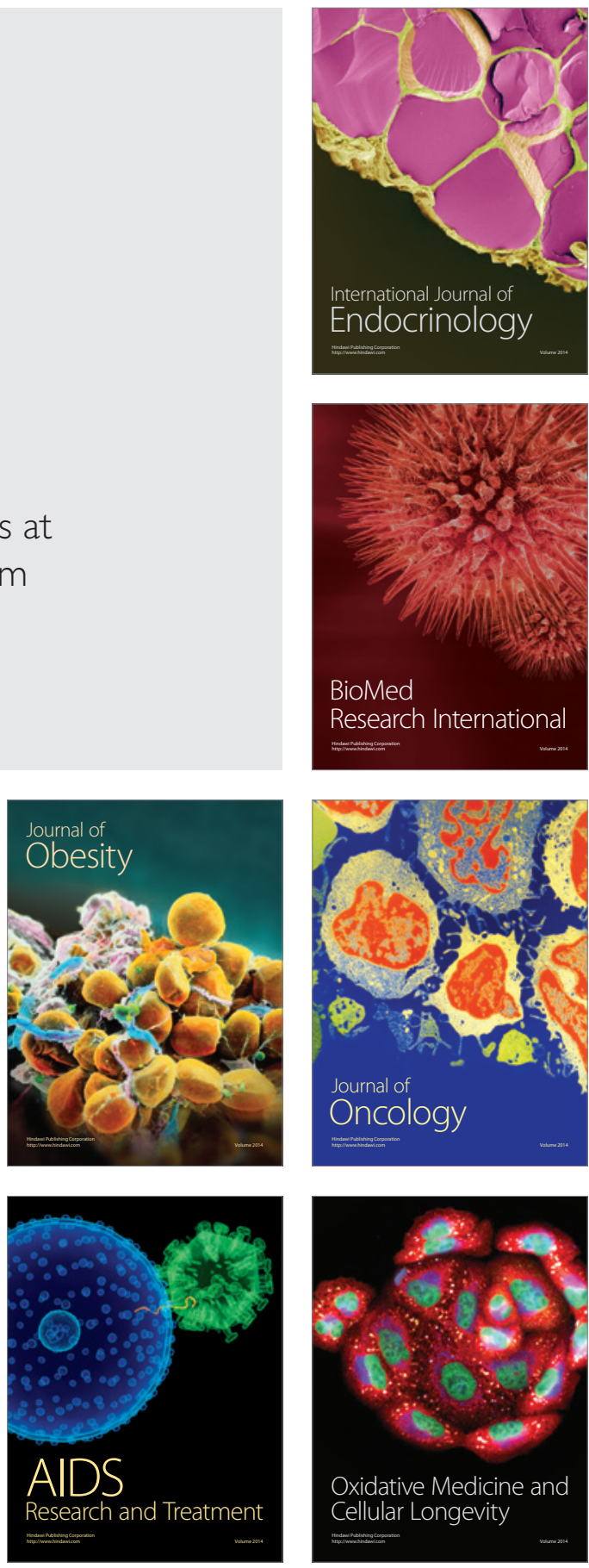